\title{
Neurological involvement in COVID-19
}

\author{
Isha Dhungana $\boldsymbol{P h D}^{\mathbf{1}}$, Prabin Shrestha $\boldsymbol{P h D}^{\mathbf{2}}$ \\ ${ }^{1,2}$ Dept of Neurosciences, B\&B Hospital, Lalitpur
}

Date of submission: $19^{\text {th }}$ December 2020

Date of acceptance: $18^{\text {th }}$ February 2021

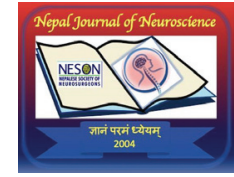

Date of publication: $1^{\text {st }}$ March 2021

\section{Abstract}

Corona Virus Disease 2019 (COVID-19) pandemic has been currently going on around the world. The causative virus, Severe Acute Respiratory Syndrome Corona Virus type 2 (SARS-Cov-2), has been detected in various human body fluids including cerebrospinal fluid.

Neurological involvement is one of the important aspects of COVID-19. Though many things in this regard have been published earlier, all the information are scattered and no article has tried to include all the information. Therefore, the main purpose of this article is to summarize all the relevant information about neurological involvement of COVID-19 in a single article.

More than one hundred recently published or pre-print articles have been collected and analyzed in this review. While searching the literatures, keywords such as COVID-19, SARS-CoV-2, encephalitis, stroke, intracranial hemorrhage, neurological manifestations, complications etc. were entered. PubMed, Medscape etc. were used as a source of information.

Neurological involvement in COVID-19 has been emerging as a matter of interest and further investigation for many who are involved in its management. Though many literatures and reports have explained various neurological aspects of COVID-19, many queries are still unanswered and needs further investigation. Spectrum of neurological involvement, exact mode and basic pathophysiology of central nervous system involvement, possibility of detection of virus in cerebrospinal fluid etc. are yet to be answered which are discussed and addressed in this review.

Based on our analysis, we have discussed on various aspects of neurological involvement in COVID-19 in this review.

Key words: COVID-19, cytokine storm, neurological complications, neurological involvement, SARS-CoV-2

Access this article online
Website: https://www.nepjol.info/index.php/NJN
DOI: https://doi.org/10.3126/njn.v18i1.33548
HOW TO CITE
Dhungana I, Shrestha P. Neurological involvement in COVID-19.
NJNS. 2021;18(1):4-14.

'ORCID id: 0000-0003-2819-3978

${ }^{2}$ ORCID id: 0000-0002-9068-4543

\author{
Address for correspondence: \\ Dr. Prabin Shrestha \\ Chief Neurosurgeon, \\ Dept of Neurosciences, \\ B\&B Hospital, Gwarko, \\ Lalitpur, Nepal \\ E-mail: prabinshrestha@hotmail.com \\ Phone: +977-9851079995
}

Copyright (C) 2021 Nepalese Society of Neurosurgeons (NESON)

ISSN: 1813-1948 (Print), 1813-1956 (Online)

This work is licensed under a Creative Commons Attribution-Non Commercial 4.0 International License.

\section{Introduction}

Corona virus called Severe Acute Respiratory Syndrome Corona Virus type 2 (SARS-CoV-2) is the cause of current pandemic of Corona Virus Disease 2019 (COVID-19). ${ }^{1}$

Though initially thought to be a kind of common flu, COVID-19 can involve almost every system and organ of Human Body. SARS-CoV-2 has been detected in different human body fluids including cerebrospinal fluid (CSF). Autopsy studies have also suggested involvement of multiple organs and systems of human body including brain and central nervous system (CNS). ${ }^{2-4}$

Though COVID-19 causes common cold and lower respiratory tract infection, at times it can cause severe complications such as severe intracerebral hemorrhage (ICH) and stroke. ${ }^{5-8}$

Since the emergence of COVID-19 in the end of December 2019 and its spread as a pandemic, many studies and researches have been carried out around the world. Many facts and figures about COVID-19 have been discovered in the short span of time. Neurological involvement has been emerging as one of the essential 
clinical aspects of COVID-19, which is still under research and investigation.

The literatures, published so far, have been found not to encompass all the neurological aspects of COVID-19 and thus not complete. They focused on only one aspect of neurological involvement. Therefore, the main goal of this review is to present and summarize the overall information about neurological aspects of COVID-19 precisely and concisely.

\section{Methods}

In this review, we have collected and analyzed more than one hundred recently published or pre-print review articles, original articles, editorials, case reports, letters to editors and existing open-source data and information about neurological aspects of the current COVID-19 pandemic. While searching the literatures, keywords such as COVID-19, SARS-CoV-2, encephalitis, stroke, intracranial hemorrhage (ICH), neurological manifestations and complications were entered. PubMed, Medscape, Center for Disease control and prevention (CDC) library and Google were used as a source of information.

Based on our analysis, we have discussed on various aspects of neurological involvement in COVID-19 in this review.

\section{SARS-CoV-2 and Central Nervous System (CNS) Invasion}

SARS-CoV-2 has been found to have high affinity with Angiotensin Converting Enzyme (ACE) 2 receptors., ${ }^{9} 10$ By binding with ACE 2 receptors with the help of spike proteins (S) present on the surface of the virus, it enters the cells of human body. ACE 2 receptors are present in numerous human body tissues and cells including endothelial cells, muscular layer of blood vessels, neurons, glial cells, epithelial cells etc. ${ }^{11}$

It has already been proved that Human CoVs (HCoVs) are neurotropic and invade human brain easily. Different pathways have been proposed regarding how the SARSCov-2 enters and invades CNS or human brain. ${ }^{12,13}$ They are i) Neuronal pathway - the primary entry port of the virus is nasal cavity where there are nerve endings of olfactory nerve. By binding to neuronal cells of olfactory nerve, as mentioned above, the virus enters brain by retrograde flow, ii) Hematogenous pathway- SARSCoV-2 can bind and enter cells of different human tissues including blood cells and thus crosses blood brain barrier (BBB) via circulation, iii) permeable BBB- when there is primary encephalopathy or encephalitis due the viral invasion, $\mathrm{BBB}$ get disrupted becoming more permeable to virus to enter the brain. $\mathrm{BBB}$ disintegration has been seen in COVID-19 encephalitis cases as evident by high CSF/ serum albumin index which is normally $<6.5 .^{14}$

\section{Neurological Involvement in COVID-19}

Neurological involvement in COVID-19 can occur any time, in the beginning or towards the end of the disease process.

Different mechanisms by which SARS-CoV-2 can produce pathological changes in human brain have been described. ${ }^{12}$ They are direct infection injury, hypoxic injury, ACE 2 mediated injury, autoimmune injury, coagulopathy etc. On the basis of our review of literatures and our observation, we have simplified the basic pathophysiology of neurological involvement in COVID-19 as has been shown in table 1 .

These pathophysiological processes ultimately lead to the three major pathological events in human brain. They are i) viral encephalitis due to direct effects of the virus on the nervous system, ii) infectious toxic encephalopathy due to post-infection immune-mediated disease and iii) different kinds of cerebro-vascular disease (CVD) due to neurological complications of the systemic effects of COVID-19.

It has been recently documented that many patients with COVID-19 developed neurological symptoms, including headache, disturbed consciousness, and paresthesia. It was also reported CNS involvement is more

\begin{tabular}{|l|l|l|l}
\hline & Pathological Process & $\begin{array}{l}\text { Etio-pathogenesis } \\
\text { Direct infection injury ACE-2 mediated } \\
\text { injury }\end{array}$ & Final Pathological Event \\
Viral Encephalitis, Myelitis
\end{tabular}

Table 1. Basic pathophysiology of neurological involvement in COVID-19 


\section{Dhungana et al}

common in more severe cases than in milder cases. ${ }^{5,6,12,15}$

Neurological involvement in COVID-19 has been evidenced by not only clinical studies but also by neuroimaging and autopsy studies.

Sanaz Katal et al studied neuroimaging findings in COVID-19 cases with neurological signs. ${ }^{16}$ They found acute abnormalities in Computerized Tomography (CT) or Magnetic Resonance Imaging (MRI) of brain in 53/90 $(59 \%)$ of cases.

Similarly, Stephane Kremer et al studied MRI Brain findings of 37 patients of severe COVID-19 with neurological features excluding ischemic infarct. ${ }^{17}$ They found majority of patients $(20 / 37,54 \%)$ had intracerebral hemorrhagic lesions with a more severe clinical presentation.

Autopsy studies and reports have shown that in most of the dead patients of COVID-19, brain tissues were hyperemic, inflamed and edematous. ${ }^{2-4}$ In some cases, virus particles have been seen under electron microscopy in the endothelial cells of brain. Autopsy also showed partial neuronal degeneration in COVID-19 deceased patients. ${ }^{4}$ Autopsy reports have also shown features of acute necrotizing encephalitis (ANE) and Acute Disseminated Encephalomyelitis (ADEM). ${ }^{18,19}$

Neurological involvement in COVID-19 has also been speculated to be a part of COVID-19 triggered autoimmunity. ${ }^{20-22}$ It has been evident by studies and case reports that Covid-19 triggered autoimmunity can lead to any kind of acute paralytic diseases like Guillain Barre Syndrome (GBS), encephalitis, myelitis, myositis etc. It has been suspected that these neuropathies can be the initial presenting symptoms of COVID-19.

Neurological involvement can affect central nervous system (CNS), peripheral nervous system (PNS) and/or neuro-muscular system (NMS). Ling Mao et al in their study found that COVID-19 involved CNS in $24.8 \%$, PNS in $8.9 \%$ and NMS in $10.7 \%$ of cases. ${ }^{6}$

Neurological involvement in COVID-19 can be classified into 3 groups from disease spectrum point of view, they are neurological manifestations, neurological complications and neurological co-morbidities.

We have classified neurological involvement in COVID-19 as shown in table 2.

\section{Neurological Manifestation of COVID-19}

The COVID-19 patients' symptoms ranged from asymptomatic to severe ones. Neurological symptoms have been observed as a common presenting manifestation of COVID-19. Headache, muscular pain of whole body, neuropathic pains such as burning and numbness sensation of limbs etc are the most common neurological symptoms that occur early in COVID-19. ${ }^{23,24}$ Neurological symptoms as a manifestation occur early either as presenting features or before development of complications.

Altered sensation of smell (anosmia) and taste (ageusia) have been observed in early stage of COVID-19. ${ }^{25-27}$ Case reports have been published that anosmia and ageusia were the first and the only symptoms in some cases. These symptoms are mainly due to involvement of olfactory bulb and olfactory nerve, which are directly exposed to the droplets from infected persons.

Epileptic fits and seizures have been encountered as an initial symptom in $\mathrm{few}^{28}$ and as a later symptom in many cases of COVID-19. As has been explained earlier, in some the virus can enter CNS directly via neuronal pathway involving brain primarily leading to fits. Huang et al reported that COVID-19 provokes the inflammatory cascade and as a result, releases inflammatory cytokines, including interleukins $2,6,7$, and 10 , tumor necrotizing $\alpha$ and the granulocyte colony-stimulating factor. ${ }^{29}$ These cytokines can drive neuronal hyperexcitability via activation of glutamate receptors and play a role in the development of acute seizures. ${ }^{30}$

Primary meningo-encephalitis cases have been reported as a presentation of COVID-19 in Japan and China. $^{31,32}$ In those cases the SARS-CoV-2 PCR was positive in CSF but not in nasopharyngeal swab. So, they

\begin{tabular}{llll}
\hline & \multicolumn{2}{c}{ Anatomical } & \multicolumn{1}{c}{ Classification } \\
Types & Examples & Types & Cxamples \\
Central Nervous & $\begin{array}{l}\text { Encephalitis, ANE, CVD, } \\
\text { GBS, ADEM, myelitis, altered } \\
\text { System (CNS) }\end{array}$ & $\begin{array}{l}\text { Neurological } \\
\text { manifestation }\end{array}$ & $\begin{array}{l}\text { Dizziness, headache, anosmia, ageusia, } \\
\text { neuromuscular pain, altered sensorium, } \\
\text { seizure }\end{array}$ \\
$\begin{array}{l}\text { Peripheral Nervous } \\
\text { System (PNS) }\end{array}$ & $\begin{array}{l}\text { Numbness, anosmia, ageusia, } \\
\text { facial palsy }\end{array}$ & $\begin{array}{l}\text { Neurological } \\
\text { complications }\end{array}$ & $\begin{array}{l}\text { Encephalitis, ANE, ADEM, CVD, GBS, } \\
\text { epilepsy, facial palsy }\end{array}$ \\
$\begin{array}{l}\text { Neuro-Muscular } \\
\text { System (NMS) }\end{array}$ & $\begin{array}{l}\text { Muscle cramps and twitching, } \\
\text { body pain }\end{array}$ & $\begin{array}{l}\text { Neurological } \\
\text { comorbidities }\end{array}$ & Old CVD, dementia, epilepsy \\
\hline
\end{tabular}

Table 2: Classification of neurological involvement in COVID-19 
suggested it to be a SARS-CoV-2 Meningitis rather than simple COVID.

As a remote possibility, different kinds of primary intra cerebral hemorrhages (ICH) and loss of consciousness have been observed as a presenting symptom in few cases. ${ }^{8,33,34}$ Most of these cases did not have any risk factor for ICH nor had any contact history for COVID-19. Their CSF was negative for SARS-CoV-2 and the ICH was thought to be due to cytokine storm.

This indicates that wide range of neurological features, from simple headache to $\mathrm{ICH}$, can be the main neurological manifestations of COVID-19.

\section{Neurological Complications of COVID-19}

Neurological symptoms can occur in COVID-19 not only as a presenting feature but also as a complication in due course of time as the disease progresses. Neurological complications often occur at the later stage of the disease unlike neurological manifestations, which appear early. Neurological complications were found to occur in severe COVID-19 as compared to non-severe cases. ${ }^{6,35}$ When neurological complications occur, it indicates possibility of poor outcome in terms of morbidity and mortality.

Mao L et al analyzed different neurological complications in 214 hospitalized patients of COVID-19 case. ${ }^{6}$ They found that neurological manifestations were present in $36.4 \%$ of total cases and neurological complications developed in more severe cases. Of severe cases, neurological complications were CVD in 5.7\%, impaired consciousness in $14.8 \%$ and musculoskeletal problems in $19.3 \%$.

Common neurological complications are severe encephalitis and status epilepticus, ischemic strokes, hemorrhagic stroke, ADEM etc.

Encephalitis and Seizure: Encephalitis in COVID-19 has been identified and reported by many studies. ${ }^{31,36,37-40}$ Studies reported that neurological symptoms appeared in wide range of timing starting from before the onset of respiratory symptoms till the late stage of COVID-19.

The neurological features in reported cases were typical for encephalitis, with irritability, confusion, and reduced consciousness etc. Some of them also had seizures, neck stiffness and psychotic symptoms. Rarer symptoms were ataxia, oscillopsia, hiccups, and bilateral facial weakness.

CSF analysis, in most of the cases, showed a pleocytosis, mostly lymphocytic, and normal in few patient. Few had positive finding of CSF PCR for SARS-CoV-2. They had encephalitis, minor respiratory symptoms, and ground glass changes on chest CT but few of them had PCR negative for SARS-CoV-2 in respiratory sample. ${ }^{31,32}$
Brain imaging like CT and/or MRI and EEG were done in those patients. In few cases, MRI showed typical high signal intensity in the medial temporal lobe ${ }^{31}$ while in others CT/MRI were normal. Similarly, EEG also showed changes like generalized slowing or focal abnormality relevant to encephalitis and types of seizure. ${ }^{36}$ EEG was found to be helpful in diagnosing the cases of nonconvulsive status epilepticus, which showed positive findings. ${ }^{37}$

Acute Necrotizing Encephalitis/Encephalopathy (ANE) is a relatively rarer and more severe type of encephalitis which used to be more common in small children. However, in COVID pandemic ANE has been detected even in adults. Several ANE and ANE like pathologies have been reported. ${ }^{41}$ George S Stoyanov et al ${ }^{18}$ reported ANE like pathology in an autopsy report who died of suspected COVID, SARS-CoV-2 was found to be negative. Similarly, Luke Dixon et $\mathrm{al}^{42}$ reported a case of ANE in COVID-19 who also died despite all the treatment. These reports show ANE has grave outcome with COVID-19.

However, Delamarre et $\mathrm{al}^{14}$ reported a case of ANE who ultimately survived with high dose of steroid and intravenous immunoglobulin (IV Ig).

The reported cases of ANE were thought to be due to virus-induced neuroimmunopathology due to a dysregulation of host immune response. All had negative SARS-CoV-2 PCR in CSF.

All the above mentioned cases of encephalitis and/ or ANE presented with seizure either in early stage as a COVID manifestation or late as a complication.

Stroke: Stroke is one of the major neurological complications of COVID-19. Different studies have shown the prevalence of stroke of about $5 \%$ among severe COVID-19 patients. $^{6,13}$ Thrombotic complication, as common as in $31 \%$ of critical cases of COVID-19, is the main cause of stroke, both ischemic and hemorrhagic. ${ }^{43}$ Stroke as a complication has been found to occur in more severe COVID-19 cases and in association with comorbidities like hypertension, diabetes, old age, cardiac problem etc. Elevated CRP, d-Dimer and coagulopathy have been found to be the risk factors and predictors of stroke in COVID-19.

Basic pathophysiology of COVID-19 are i) Leukocytosis and thrombocytopenia, ii) an elevated prothrombin time and partial thromboplastin time, iii) elevated levels of fibrinogen and D-dimer and iv) antiphospholipid antibodies / Antiphospholipid syndrome. All these factors can lead to both thrombotic and hemorrhagic complications.

Some of the typical features of strokes that we observed in our review of COVID-19 are new onset strokes, sudden strokes, strokes in younger group, large 


\section{Dhungana et al}

vessel stroke, multi focal and venous strokes etc. occurring as neurological complications. ${ }^{7,13,44,45}$

Julie Helms et al reported asymptomatic stroke associated with COVID-19. They reported 13 cases without focal signs but some encephalopathic features. Of 13, 11 had frontotemporal hypoperfusion and $2 \mathrm{had}$ a small acute ischemic stroke in DWI. ${ }^{46}$

Beyrouti et al and Oxley et al reported large vessel stroke in COVID-19. ${ }^{7,44}$ All the patients had large vessel occlusion namely vertebral artery (VA), middle cerebral artery (MCA), posterior cerebral artery (PCA), superior cerebellar artery (SCA) etc. and had markedly elevated D-dimer levels $(\geq 1000 \mu \mathrm{g} / \mathrm{L})$. It has been postulated that COVID-19 might stimulate the production of antiphospholipid antibodies (aPL) and may cause cerebral large vessel thrombosis leading o large vessel stroke. ${ }^{45}$

Hemorrhagic complication as $\mathrm{ICH}$, has also been seen in COVID. Coagulopathy and encephalopathy as a part of severe multi-systemic inflammatory response of COVID-19 are the main causes of ICH. ICH has been found to occur in more aged people and is associated with poorer outcome. ${ }^{17} \mathrm{ICH}$ cases were primary $\mathrm{ICH}$ and hemorrhagic transformation of ischemic strokes. Cases with primary ICH with sudden death in COVID has been reported. ${ }^{47}$ Other causes of ICH in COVID-19 are anticoagulation in normal or higher dose, aneurysmal bleed, extra-corporeal membrane oxygenation (ECMO) induced ICH etc.

Acute Disseminated Encephalomyelitis (ADEM): ADEM is a syndrome of multifocal demyelination which generally presents with focal neurological symptoms, often with encephalopathy. ADEM and Myelities are considered as post infectious disease, often post viral. ADEM has been found to be one of the rarer neurological complications of COVID-19..$^{21,41,48}$ CSF of those patients was normal and negative for SARS-CoV-2. They improved after treatment with intravenous immunoglobulin (IVIg), methylprednisolone and/or dexamethasone. R Ross Reichard reported a patient who died of COVID-19 whose autopsy report revealed features of ADEM. ${ }^{19}$ Therefore, ADEM should be considered a potentially treatable cause of profound encephalopathy or multifocal neurological deficits in COVID-19.

Guillain Barre Syndrome (GBS): GBS, as confirmed by CSF examination and Nerve conduction study, has been observed as a complication of COVID-19.41,49-53 But, CSF was negative for SARS-CoV-2 in all the reported cases of GBS. Morbidity and mortality was found to be higher in COVID GBS cases in COVID-19. One report showed that of 5 cases of GBS 1 had improvement, 1 had mild improvement and 3 had poor outcome. Another case report in Italy expired despite all the efforts. GBS in COVID-19 patients is possibly caused by dysregulation of immune system leading to COVID-19 triggered autoimmune neuropathies. ${ }^{50}$

Neuromuscular Disorders (NMD): NMD has been observed in different studies and case reports of COVID-19. Viral myositis, rhabdomyolysis, GBS etc are few examples. SARS was also found to have complications of NMD in the form of polyneuropathy and myopathy when the disease gets severe. ${ }^{35}$ Elevated level of Creatine Kinase (CK) was observed in these NMDs. Mao et al also found level of CK very high $(>10,000)$ in $19.3 \%$ of COVID-19 cases leading to painful muscle weakness. ${ }^{6}$ Studies have shown that NMD in the form of fatigue and myalgia can occur in $44-70 \%$ of cases of COVID- $19 .{ }^{22}$

Few potential neuromuscular complications of COVID-19 are- i) development of new NMD like GBS, myositis, myopathy or polyneuropathy, ii) exacerbation of previously existing or unrecognized NMD, iii) complications of immunosuppressant/ immunomodulating therapies for autoimmune NMD, iv) treatment complications of COVID-19 like antiviral interacting with others, iv) complications of vaccinations like possible inflammatory neuropathy etc.

Neuropsychiatric Disorders: Neuropsychiatric problems are other complications of COVID during or after the disease course. Nina Vindegaard et al did an extensive study of literatures on mental health consequences in covid -19 and related patients. ${ }^{54}$ They found many more cases of psychiatric problem due to pandemic rather than due to COVUD-19 itself. They also found a high level of post traumatic stress symptoms, in $96.2 \%$ of COVID-19 patients. Another study showed 125 patients had neurological involvement associated with COVID-19. ${ }^{15}$ Of 125 cases $23(18 \%)$ had a neuropsychiatric diagnosis, including $10(8 \%)$ psychosis, $6(5 \%)$ neurocognitive (dementia-like) syndrome, $4(3 \%)$ an affective disorder and the rest others.

\section{Neurological Comorbidities (NCoM) Concomitant with COVID-19}

Various comorbidities have been found to be associated with COVID-19, which increase the complications and severity of the disease. One study reviewed 22,753 COVID-19 patient population from different countries, of which $42.3 \%$ patients were without any chronic comorbid condition, while $57.7 \%$ had one or more comorbidities. ${ }^{55}$ Hypertension followed by diabetes and cardiovascular diseases were the most common comorbidity seen in COVID-19 positive patients across major epicenters world-wide. The study showed that neurological comorbidities are not that commonly associated with 
COVID-19. In other language, neurological comorbidities are low risk factors for contracting COVID-19.

Similarly, in another study of 576 patients, NCoM included $40(6.9 \%)$ cases of CVD, $32(5.5 \%)$ cognitive disorders, $24(4.1 \%)$ neuromuscular and spinal diseases and $16(2.7 \%)$ movement disorders. Patients with NCoM were older, more disabled, had more vascular risk factors and comorbidities and fewer clinical symptoms of COVID-19. Presence of NCoM was an independent predictor of death in COVID-19 and was also associated with more severe pneumonia and ARDS in COVID-19 though it was not statistically significant.

\section{SARS-CoV-2 in CSF}

Even though wide range of neurological involvement in COVID-19 has already been known, there are still many things yet to be understood in this regard. Possibility of detection of SARS-CoV-2 in CSF among various neurological conditions in COVID-19 is one of them, which is not yet well explained.

Cases have been reported in which the virus was isolated in CSF though not in nasopharyngeal swab. ${ }^{13,31}$ However, in many cases of COVID-19 with stroke, GBS, myelitis etc the virus couldn't be detected in $\mathrm{CSF}^{48-50}$ This indicates a need of study and research to explain and identify the factors which are responsible for presence or absence of the virus in CSF.

ACE 2 has been demonstrated to be expressed in neurons and the brain ${ }^{11}$ potentially allowing SARSCoV-2 to cross the blood-brain barrier. CNS or brain involvement in COVID-19 seems to occur largely by two factors. One is by direct invasion of brain by virus leading to viral encephalitis. Another is by the immune mediated systemic effect of COVID-19 leading to cytokine storm, thromboembolism, antiphospholipid syndrome, coagulopathy etc. These ultimately lead to different kinds of encephalopathy and CVD. These two factors are different yet they may complement each other.

When there is direct viral invasion of brain, more and more viral replication occurs. If the infection is severe enough there may be disruption of BBB leading to more entry of virus into the brain from the systemic viral infection via blood circulation. Then virus spreads to different parts of brain through CSF. As a result, virus can be detected in CSF. ${ }^{11,13,31}$

In contrary, when brain is affected by the cytokine storm it is the inflammatory response rather than direct viral invasion that produces other pathologies like, peripheral neuropathy, GBS, myelopathy, ANE, ADEM, CVD, etc as a result virus is not detected in CSF. ${ }^{8,53}$ Case reports showed SARS-CoV-2 negative in CSF in the cases of ANE. ${ }^{14}$ This is because most of these reported ANE cases were the cases of viral infection induced neuroimmunopathy.

Moreover, virus detection in CSF also seems to depend on the severity of the disease and thus viral load in nervous tissue.

Reports have shown that in more severe and fulminant cases as reported by Moriguchi and $\mathrm{Li}, \mathrm{BBB}$ is disrupted and thus CSF has the virus. ${ }^{13,31}$ Similarly, in a severe case of meningoencephalitis complicated with intracranial hemorrhage, virus was isolated even in intracranial blood and $\mathrm{CSF}^{33}$

In contrary, in mild cases, CSF samples were suggestive of encephalitis but negative for SARS-CoV-2. ${ }^{37,57}$ In less severe cases of ICH also CSF was negative for the virus. ${ }^{58}$

This shows that viral load plays a role in determining presence or absence of virus in CSF. Therefore, underlying etiopathology of brain involvement and severity of the disease are the main determining factors predicting presence of the virus in CSF as has been shown in table 3 .

\section{Cytokine Storm and Its Neurological Consequences in COVID-19}

Following any infection, there is cytokine release and inflammatory response. If the infection is mild the resultant inflammation is also mild leading to milder symptoms like fever, headache, body pain and other flu-like symptoms. The compensatory immune response finally takes over the infection and inflammation, and the patient gets cured.

But when the infection is severe it can result in severe inflammatory response and at time what we call Cytokine storm occurs. The term "cytokine storm" was first coined in 1993 to describe a graft- vs.-host disease. ${ }^{59}$ Cytokine

\section{Pathological process of CNS involvement in COVID-19}

Direct invasion by virus

Immune mediated/systemic complication

\begin{tabular}{c|c|c|c} 
& $\begin{array}{c}\text { Severe Encephalitis (high viral } \\
\text { load) }\end{array}$ & $\begin{array}{c}\text { Mild Encephalitis (Low viral } \\
\text { load) }\end{array}$ & $\begin{array}{c}\text { CVD, Encephalopathy, ANE, } \\
\text { ADEM, GBS }\end{array}$ \\
\hline $\begin{array}{c}\text { SARS-CoV-2 in } \\
\text { CSF }\end{array}$ & +ve & -ve & -ve \\
\hline
\end{tabular}

Table 3: Detection of SARS-CoV-2 in CSF 


\section{Dhungana et al}

storm occurs when an immune system is over-activated by infection, drug, and/or some other stimuli, leading to high levels of cytokines (IFN, IL, chemokines, TNF, etc.). When these cytokines are released into circulation there is widespread and detrimental impact on multiple organs. A cytokine storm is nearly always pathogenic because of its detrimental effects on the host.

As per SARS-CoV-2 infection, initially it was thought to affect primarily respiratory tract. But later it has been found that it affects other human body systems as well like gastrointestinal system, nervous system etc. through ACE 2. In COVID-19 disease, cytokine storm is common in patients with severe-to-critical symptoms. Lymphocytes and NK cell counts are sharply reduced with elevations in levels of D-dimer, C-reactive protein (CRP), ferritin, and procalcitonin. Elevated CRP and ferritin levels are associated with the onset of a cytokine storm in patients. ${ }^{60,61}$

Elevation of IL-6 was most frequently measured and detected in severe cases of SARS-CoV-2 infection. ${ }^{62}$

As COVID-19 progresses, the number of neutrophils in circulation gradually increase; thus, elevated neutrophil levels may be useful for predicting the severity of disease. ${ }^{63}$ Zhang BC et al reported that the neutrophil-tolymphocyte ratio (NLR) combined with IgG might be a better predictor than neutrophil count alone in predicting the severity of COVID-19. ${ }^{64}$
All these inflammatory process finally leads to septic shock, organ failure, coagulopathy and involves different organs including CNS.

\section{Management of Neurological Disorders in COVID-19}

Basic management philosophy of neurological problems in COVID-19 is the same as in Non-COVID cases. However, few things that have been found to be helpful and thus to be considered in the treatment of COVIDF-19 are i) timely identification of neurological symptoms and complications, ii) prompt intervention like surgery, thrombolysis, ventilation etc, iii) adequate prevention of thrombosis while preventing its possible complications, iv) antiviral treatment for respiratory and nervous infection, v) Intravenous Immunoglobulin (IV Ig) therapy, vi) high dose of steroid Methylprednisolone or Dexamethasone. Literatures show that above treatment protocols were applied in many cases, which saved many lives as shown in table 4.,2,31,41,47,56,64 However severe encephalitis such as cases of acute necrotizing encephalitis have worse outcome irrespective of the treatment protocol.

\begin{tabular}{|c|c|c|c|}
\hline$\overline{\text { Article }}$ & $\overline{\text { Author }}$ & Treatment protocol & Outcome \\
\hline $\begin{array}{l}\text { A Rare Case of } \\
\text { Acute Hemorrhagic } \\
\text { Leukoencephalitis in a } \\
\text { COVID-19 Patient }\end{array}$ & $\begin{array}{l}\text { Yong M H, Chan Y F, Liu J, } \\
\text { Sanamandra SK, Kheok SW, } \\
\text { Lim KC, et al }\end{array}$ & $\begin{array}{l}\text { Intravenous antiviral, } \\
\text { enoxaparin, intravenous } \\
\text { immunoglobulin, high dose } \\
\text { of methylprednisolone }\end{array}$ & Survived \\
\hline $\begin{array}{l}\text { COVID-19-related acute } \\
\text { necrotizing } \\
\text { encephalopathy with brain } \\
\text { stem involvement in a } \\
\text { patient with aplastic anemia }\end{array}$ & $\begin{array}{l}\text { Dixon L, Varley J, } \\
\text { Gontsarova A, Mallon D, } \\
\text { Tona F, Muir D, et al }\end{array}$ & $\begin{array}{l}\text { Intravenous antiviral, high } \\
\text { dose of Methylprednisolone/ } \\
\text { Dexamethasone, mechanical } \\
\text { ventilation, }\end{array}$ & $\begin{array}{l}\text { Died of respiratory failure } \\
\text { and acute encephalopathy }\end{array}$ \\
\hline $\begin{array}{l}\text { A first Case of Meningitis/ } \\
\text { Encephalitis associated with } \\
\text { SARS-Coronavirus-2 }\end{array}$ & $\begin{array}{l}\text { Moriguchi T, Harii N, Goto } \\
\text { J, Harada D, Sugawara H 3, } \\
\text { Takamino J, et al }\end{array}$ & $\begin{array}{l}\text { Intravenous antiviral, } \\
\text { antibiotics, antiepileptics }\end{array}$ & $\begin{array}{l}\text { Improving at the time of } \\
\text { manuscript writing }\end{array}$ \\
\hline $\begin{array}{l}\text { Encephalitis as a clinical } \\
\text { manifestation of COVID-19 }\end{array}$ & Ye M, Ren Y, Lv T & $\begin{array}{l}\text { Supportive management, } \\
\text { intravenous antivirals, } \\
\text { antibiotics }\end{array}$ & Survived \\
\hline $\begin{array}{l}\text { Central Nervous System } \\
\text { Involvement by Severe } \\
\text { Acute Respiratory Syndrome } \\
\text { Coronavirus -2 (SARS- } \\
\text { CoV-2) }\end{array}$ & $\begin{array}{l}\text { Paniz-Mondolfi A, Bryce } \\
\text { C, Grimes Z, Gordon RE, } \\
\text { Reidy J, Lednicky J, et al }\end{array}$ & $\begin{array}{l}\text { Enoxaparin, } \\
\text { hydroxychloroquine }\end{array}$ & $\begin{array}{l}\text { Died of cardiac } \\
\text { complications and acute } \\
\text { encephalitis }\end{array}$ \\
\hline $\begin{array}{l}\text { COVID-19-associated } \\
\text { acute disseminated } \\
\text { encephalomyelitis (ADEM) }\end{array}$ & $\begin{array}{l}\text { Parsons T, Banks S, Bae } \\
\text { C, Gelber J, Alahmadi H, } \\
\text { Tichauer M }\end{array}$ & $\begin{array}{l}\text { High dose of } \\
\text { methylprednisolone, } \\
\text { intravenous immunoglobulin }\end{array}$ & Survived \\
\hline
\end{tabular}

Table 4: Literatures showing treatment protocol and outcome 


\section{Conclusion}

In this current COVID-19 pandemic, neurological involvement has been emerging as a field of interest and attention. Many case reports, studies and reviews have been published. However, the complete review is not yet. This review has attempted to encompass all the aspects of neurological involvement in COVID-19.

COVID -19 can affect brain and CNS, either by direct viral invasion or by cytokine storm.

Neurological involvement in COVID-19 can occur as a manifestation, complication or comorbidities. In most of the cases, neurological manifestations occur early and neurological complications late. Neurological complication, when occur, has been found to indicate poor outcome.

\section{Conflict of Interest: None Source(s) of support: None}

\section{References}

1. Robin T. Pandemic potential of 2019-nCoV. Lancet Infect Dis. 2020;20(3):280. https://doi.org/10.1016/ S1473-3099(20)30068-2

2. Paniz-Mondolfi A, Bryce C, Grimes Z, Gordon RE, Reidy J, Lednicky J, et al. Central Nervous System Involvement by Severe Acute Respiratory Syndrome Coronavirus-2 (SARS-CoV-2). J Med Virol. 2020;92(7):699-702. https://doi.org/10.1002/ jmv. 25915

3. Azzi L, Carcano G, Gianfagna F, Paolo G, Daniela DG, Angelo G, et al. Saliva is a reliable tool to detect SARS-CoV-2. J Infect. 2020; 81(1): E45-E50. https:// doi.org/10.1016/j.jinf.2020.04.005

4. Xu Z, Shi L, Wang Y, Jiyuan Zhang, Lei Huang, Chao Zhang, et al. Pathological findings of COVID-19 associated with acute respiratory distress syndrome. Lancet Respir Med. 2020;8(4):420-22. https://doi. org/10.1016/S2213-2600(20)30076-X

5. Asadi-Pooya A A, Simani L. Central nervous system manifestations of COVID-19: A systematic review. J Neurol Sci. 2020;413:116832. https://doi. org/10.1016/j.jns.2020.116832

6. Mao L, Jin H, Wang M, Yu H, Shengcai C, Quanwei $\mathrm{H}$, et al. Neurologic Manifestations of Hospitalized Patients with Coronavirus Disease 2019 in Wuhan, China. JAMA Neurol. 2020;77(6):1-9. https://doi. org/10.1001/jamaneurol.2020.1127

7. Oxley T J, Mocco J, Majidi S, Christopher P K, Hazem S, Singh IP, et al. Large-Vessel Stroke as a Presenting Feature of Covid-19 in the Young. N Engl
J Med. 2020;382(20):e60. https://doi.org/10.1056/ NEJMc2009787

8. Bao Y, Lin SY, Cheng ZH, Jun X, Yan PS, Qi Z, et al. Clinical Features of COVID-19 in a Young Man with Massive Cerebral Hemorrhage-Case Report. SN Compr Clin Med. 2020;2:703-09. https://doi. org/10.1007/s42399-020-00315-y

9. Hoffmann M, Kleine-Weber H, Schroeder S, Nadine K, Tanja H, Sandra E, et al. SARS-CoV-2 Cell Entry Depends on ACE2 and TMPRSS2 and Is Blocked by a Clinically Proven Protease Inhibitor. Cell. 2020;181(2):271-80. https://doi.org/10.1016/j. cell.2020.02.052

10. Machhi J, Herskovitz J, Senan AM, Dutta D, Nath B, Oleynikov MD, et al. The Natural History, Pathobiology, and Clinical Manifestations of SARSCoV-2 Infections. J Neuroimmune Pharmacology. 2020:1-28. https://doi.org/10.1007/s11481-02009944-5

11. Xia H, Lazartigues E. Angiotensin-Converting enzyme 2 in the brain: properties and future directions. J Neurochem. 2008;107:1482-94. https:// doi.org/10.1111/j.1471-4159.2008.05723.x

12. Wu Y, Xu X, Chen Z, Duan J, Hashimoto K, Yang L, et al. Nervous system involvement after infection with COVID-19 and other coronaviruses. Brain Behav Immun. 2020;87:18-22. https://doi.org/10.1016/j. bbi.2020.03.031

13. Li YC, Bai WZ, Hashikawa T. The neuroinvasive potential of SARS-CoV2 may play a role in the respiratory failure of COVID-19 patients. J Med Virol. 2020;92(6):552-55. https://doi.org/10.1002/ jmv. 25728

14. Delamarre L, Gollion C, Grouteau G, Rousset D, Jimena G, Roustan J, et al. COVID-19-associated acute necrotising encephalopathy successfully treated with steroids and polyvalent immunoglobulin with unusual IgG targeting the cerebral fibre network. J Neurol Neurosurg Psychiatry. 2020;91(9):1004-6. https://doi.org/10.1136/jnnp-2020-323678

15. Varatharaj A, Thomas N, Ellul MA, Davies NW, Pollak TA, Tenorio EL, et al. Neurological and neuropsychiatric complications of COVID-19 in 153 patients: a UK-wide surveillance study. Lancet Psychiatry. 2020;7(10):875-82. https://doi. org/10.1016/S2215-0366(20)30287-X

16. Katal S, Balakrishnan S, Gholamrezanezhad A. Neuroimaging and neurologic findings in COVID-19 and other coronavirus infections: A systematic review in 116 patients. J Neuroradiol. 2020 (Available online 27 June 2020). https://doi.org/10.1016/j. neurad.2020.06.007 


\section{Dhungana et al}

17. Kremer S, Lersy F, de Sèze J, Ferré JC, Maamar A, Carsin-Nicol B, et al. Brain MRI Findings in Severe COVID-19: A Retrospective Observational Study. Radiology 2020 (Available online:Jun 16 2020). https://doi.org/10.1148/radiol.2020202222

18. Stoyanov G S, Lyutfi E, Dzhenkov D L, Petkova L. Acute Necrotizing Encephalitis in Viral Respiratory Tract Infection: An Autopsy Case Report. Cureus 12(5). https://doi.org/10.7759/cureus

19. Reichard R R, Kashani K B, Boire N A, Constantopoulos E, Guo Y, Lucchinetti C F. Neuropathology ofCOVID-19: a spectrum of vascular and acute disseminated encephalomyelitis (ADEM)like pathology. Acta Neuropathol. 2020;140(1);1-6. https://doi.org/10.1007/s00401-020-02166-2

20. Dalakas MC. Guillain-Barré syndrome: The first documented COVID-19-triggered autoimmune neurologic disease. Neurol Neuroimmunol Neuroinflamm. 2020; 7(5): e781. https://doi. org/10.1212/NXI.0000000000000781

21. Valiuddin $H$, Skwirsk $B$, and Paz-Arabo P. Acute transverse myelitis associated with SARSCoV-2: A Case-Report. Brain Behav Immun Health. 2020;5:100091. https://doi.org/10.1016/j. bbih.2020.100091

22. Amanda CG, Anthony AA. COVID-19 and neuromusculardisorders. Neurology.2020;94:959-69. https://doi.org/10.1212/WNL.0000000000009566

23. Lahiri D, Ardila A. COVID-19 Pandemic: A Neurological Perspective. Cureus 2020;12(4):e7889. https://doi.org/10.7759/cureus.7889

24. Ardila A, Lahiri D. Executive dysfunction in COVID-19 patients. Diabetes Metab Syndr. 2020;14(5):1377-78. https://doi.org/10.1016/j. dsx.2020.07.032

25. Giacomelli A, Laura Pezzati L, Conti F, Bernacchia D, Siano M, Oreni L, et al. Self-reported Olfactory and Taste Disorders in Patients With Severe Acute Respiratory Coronavirus 2 Infection: A Crosssectional Study. Clin Infect Dis 2020;71(15):889-90. https://doi.org/10.1093/cid/ciaa330

26. Chung TW, Siddharth S, Zhang AJ, Chan KH, Li H, Wong FK, et al. Olfactory Dysfunction in Coronavirus Disease 2019 Patients: Observational Cohort Study and Systematic Review. Open Forum Infect Dis. 2020;7(6). https://doi.org/10.1093/ofid/ ofaa199

27. Yin R, Feng W, Wang T, Chen G, Wu T, Chen D, et al. Concomitant neurological symptoms observed in a patient diagnosed with coronavirus disease 2019 . J Med Virol. 2020;92(10):1782-84. https://doi. org/10.1002/jmv.25888
28. Karimi N, Razavi S A, Rouhani N. Frequent Convulsive Seizures in an Adult Patient with COVID-19: A Case Report. Iran Red Crescent Med J. 2020; 22(3):e102828. https://doi.org/10.5812/ ircmj. 102828

29. Huang C, Wang Y, Li X, Ren L, Zhao J, Hu Y, et al. Clinical features of patients infected with 2019 novel coronavirus in Wuhan, China. Lancet. 2020;395(10223):497-506. https://doi.org/10.1016/ S0140-6736(20)30183-5

30. Libbey JE, Kennett NJ, Wilcox KS, White HS, Fujinami RS. Interleukin6, produced by resident cells of the central nervous system and infiltrating cells, contributes to the development of seizures following viral infection. J Virol. 2011;85(14):6913-22. https:// doi.org/10.1128/JVI.00458-11

31. Moriguchi T, Harii N, Goto J, Harada D, Sugawara $\mathrm{H}$ 3, Takamino J, et al. A first case of meningitis/ encephalitis associated with SARS-Coronavirus-2. Int J Infect Dis. 2020;94:55-8. https://doi. org/10.1016/j.ijid.2020.03.062

32. Al-olama M, Rashid A, Garozzo D. COVID19-associated meningoencephalitis complicated with intracranial hemorrhage: a case report. Acta Neurochirurgica. 2020;162:1495-99. https://doi. org/10.1007/s00701-020-04402-w

33. Craen A, Logan G, Ganti L. Novel Coronavirus Disease 2019 and Subarachnoid Hemorrhage: A Case Report. Cureus. 2020;12(4):e7846. https://doi. org/10.7759/cureus.7846

34. Tsai LK, Hsieh ST, Chao CC, Chen YC, Lin YH, Chang $\mathrm{SC}$, et al. Neuromuscular disorders in severe acute respiratory syndrome. Arch Neurol. 2004; 61:166973. https://doi.org/10.1001/archneur.61.11.1669

35. Sohal S, Mossammat M. COVID-19 presenting with seizures. ID Cases. 2020 (e-pub ahead of print). https://doi.org/10.1016/j.idcr. https://doi. org/10.1016/j.idcr.2020.e00782

36. Bernard-Valnet R, Pizzarotti B, Anichini A, Demars Y, Russo E, Schmidhauser M, et al. Two patients with acute meningoencephalitis concomitant with SARSCoV-2 infection. Eur J Neurol. 2020; e43-e44. https://doi.org/10.1101/2020.04.17.20060251

37. Wong PF, Craik S, Newman P, Makan A, Srinivasan $\mathrm{K}$, Crawford E, et al. Lessons of the month 1: a case of rhombencephalitis as a rare complication of acute COVID-19 infection. Clin Med (Lond). 2020;20(3):293-4. https://doi.org/10.7861/ clinmed.2020-0182

38. Pilotto A, Odolini S, Stefano Masciocchi S, Comelli A, Volonghi I, Gazzina S, et al. Steroid-responsive encephalitis in Coronoavirus disease 2019. Ann 
Neurol. 2020;88(2):423-7. https://doi.org/10.1002/ ana. 25783

39. Duong L, Xu P, Liu A. Meningoencephalitis without respiratory failure in a young female patient with COVID-19 infection in downtown Los Angeles, early April 2020. Brain Behav Immun. 2020;87:33. https://doi.org/10.1016/j.bbi.2020.04.024

40. Ellul MA, Benjamin L, Singh B, Lant S, Michael $\mathrm{BD}$, Easton A, et al. Neurological associations of COVID-19. Lancet Neurol. 2020;19(9):767-783. https://doi.org/10.1016/S1474-4422(20)30221-0

41. Dixon L, Varley J, Gontsarova A, Mallon D, Tona F, Muir D, et al. COVID-19-related acute necrotizing encephalopathy with brain stem involvement in a patient with aplastic anemia. Neurol Neuroimmunol Neuroinflamm. 2020; 7(5): e789. https://doi. org/10.1212/NXI.0000000000000789

42. Klok FA, Kruip MJHA, van der Meer NJM, Arbous MS, Gommers DA, Kant KM, et al. Incidence of thrombotic complications in critically ill ICU patients with COVID-19. Thromb Res. 2020;191:145-47. https://doi.org/10.1016/j.thromres.2020.04.013

43. Beyrouti R, Adams M E, Benjamin L, Cohen H, Farmer SF, Goh YY, et al. Characteristics of ischaemic stroke associated with COVID-19. J Neurol Neurosurg Psychiatry. 2020;91(8)889-91. https://doi.org/10.1136/jnnp-2020-323586

44. Zhang Y, Xiao M, Zhang S, Xia P, Cao W, Jiang W, et al. Coagulopathy and Antiphospholipid Antibodies in Patients with Covid-19. N Engl J Med. 2020: e38. https://doi.org/10.1056/NEJMc2007575

45. Helms J, Kremer S, Merdji H, Clere-Jehl R, Schenck M, Kummerlen C, et al. Neurologic Features in Severe SARS-CoV-2 Infection. N Engl J Med. 2020;382(23):2268-70. https://doi. org/10.1056/NEJMc2008597 A. Catastrophic Intracranial Hemorrhage in Two Critically Ill Patients with COVID-19. Neurocrit Care 2020;1-5. https://doi.org/10.1007/s12028-02000993-5

47. Parsons T, Banks S, Bae C, Gelber J, Alahmadi $\mathrm{H}$, Tichauer M. COVID-19-associated acute disseminated encephalomyelitis (ADEM). J Neurol. 2020:1-4. https://doi.org/10.1007/s00415-02009951-9

48. Zhao H, Shen D, Zhou H, Liu J, Chen S. GuillainBarré syndrome associated with SARS-CoV-2 infection: causality or coincidence? Lancet Neurol. 2020;19(5):383-4. https://doi.org/10.1016/S14744422(20)30109-5

49. Dalakas MC. Guillain-Barré syndrome: The first documented COVID-19-triggered autoimmune neurologic disease: More to come with myositis in the offing. Neurol Neuroimmunol Neuroinflamm. 2020;7(5): e781. https://doi.org/10.1212/ NXI.0000000000000781

50. Galassi G, Marchioni A. Facing acute neuromuscular diseases during COVID-19 pandemic: focus on Guillain-Barré syndrome. Acta Neurol Belg. 2020. https://doi.org/10.1007/s13760-020-01421-3

51. Agosti E, Giorgianni A, D’Amore F, Vinacci G, Balbi $\mathrm{S}$, Locatelli $\mathrm{D}$. Is Guillain-Barrè syndrome triggered by SARS-CoV-2? Case report and literature review. Neurol Sci. 2020. https://doi.org/10.1007/s10072020-04553-9

52. Toscano G, Palmerini F, Ravaglia S, Ruiz L, Invernizzi P, Cuzzoni MG, et al. Guillain-Barré Syndrome Associated with SARS-CoV-2. N Engl J Med 2020; 382:2574-2576 https://doi.org/10.1056/ NEJMc2009191

53. Nina V, Benros ME. COVID-19 pandemic and mental health consequences: Systematic review of the current evidence. Brain Behav Immun. 2020;89:531542. https://doi.org/10.1016/j.bbi.2020.05.048

54. Bajgain TK, Badal S, Bajgain BB, Santana JM. Prevalence of comorbidities among individuals with COVID-19: A rapid review of current literature. Am J Infect Control. 2020 (Online available 9 July 2020). https://doi.org/10.1016/j.ajic.2020.06.213

55. García-Azorín D, Martínez-Pías E, Javier Trigo J, Hernández-Pérez I, Valle-Peñacoba G, Talavera B, et al. Neurological Comorbidity Is a Predictor of Death in Covid-19 Disease: A Cohort Study on 576 Patients. Front Neurol. 2020;11:781. https://doi.org/10.3389/ fneur.2020.00781

56. Ye M, Ren Y, Lv T. Encephalitis as a clinical manifestation of COVID-19. Brain Behav Immun. 2020;88:945-6. https://doi.org/10.1016/j. bbi.2020.04.017

57. Saiegh AF, Ghosh R, Leibold A, Avery MB, Schmidt RF, Theofanis T, et al. Status of SARS-CoV-2 in cerebrospinal fluid of patients with COVID-19 and stroke. J Neurol Neurosurg Psychiatry 2020;91(8):846-8. https://doi.org/10.1136/jnnp2020-323522

58. Ferrara JL, Abhyankar S, Gilliland DG. Cytokine storm of graftversus-host disease: a critical effector role for interleukin-1. Transplant Proc. 1993;25:121667.

59. Chen N, Zhou M, Dong X, Jieming Qu J, Fengyun Gong F, Yang Han Y, et al. Epidemiological and clinical characteristics of 99 cases of 2019 novel coronavirus pneumonia in Wuhan, China: a descriptive study. Lancet. 2020;395:507-13. https:// doi.org/10.1016/S0140-6736(20)30211-7 


\section{Dhungana et al}

60. Chen C, Zhang XR, Ju ZY, He WF. Advances in the research of cytokine storm mechanism induced by Corona Virus Disease 2019 and the corresponding immunotherapies. Zhonghua Shao Shang Za Zhi. 2020. https://doi.org/10.3760/ cma.j.cn501120-20200224-00088

61. Zhou Y, Fu B, Zheng X, Wang D, Zhao C, qi $\mathrm{Y}$, et al. Aberrant pathogenic GM-CSF+T cells and inflammatory CD14+CD16+ monocytes in severe pulmonary syndrome patients of a new coronavirus. BioRxiv. 2020. https://doi. org/10.1101/2020.02.12.945576
62. Chen J, Fan H, Zhang L, Zhu M, Zhou Y, Zhang H, et al. Retrospective analysis of clinical features in 101 death cases with COVID-19. medRxiv. 2020. https:// doi.org/10.1101/2020.03.09.20033068

63. Zhang BC, Zhou XY, Zhu CL, Song Y, Feng F, Qiu $\mathrm{Y}$, et al. Immune phenotyping based on neutrophilto-lymphocyte ratio and $\mathrm{IgG}$ predicts disease severity and outcome for patients with COVID-19. medRxiv 2020.03.12.20035048. https://doi.org/10.1101/2020. 03.12.20035048

64. Yong M H, Chan Y F, Liu J, Sanamandra SK, Kheok SW, Lim KC, et al. A Rare Case of Acute Hemorrhagic Leukoencephalitis in a COVID-19 Patient. J Neurol Sci. 2020. https://doi.org/10.1016/j.jns.2020.117035 